\title{
PENGEMBANGAN BUKU TEKS BIDANG BIMBINGAN SOSIAL BERBASIS MASALAH UNTUK MENINGKATKAN KEMAMPUAN SISWA MENGATASI MASALAH KONFLIK INTERPERSONAL
}

\author{
Tripina $^{1}$ \\ Dra. Retty Filliani \\ Susi Fitri, S.Pd, M.Si, Kons ${ }^{3}$
}

\begin{abstract}
Abstrak
Penelitian pengembangan ini bertujuan untuk menghasilkan suatu produk pembelajaran berbentuk buku teks yang dapat digunakan sebagai penunjang guru Bimbingan dan Konseling dalam memberikan bimbingan kepada siswa dalam menangani konflik interpersonal. Metode penelitian yang digunakan adalah metode Penelitian dan Pengembangan (Research and Development) /R\&D yang dikembangkan oleh Borg dan Gall. Pengembangan buku teks dapat dijadikan sebagai pedoman guru Bimbingan dan Konseling dalam memberikan layanan bidang bimbingan sosial baik secara klasikal maupun kelompok terhadap masalah konflik interpersonal. Buku teks dibuat karena metode yang digunakan guru Bimbingan dan Konseling dalam penanganan konflik siswa, masih dilakukan secara otodidak, berdasarkan pengalaman, membaca dari berbagai sumber media, karena belum memiliki buku panduan secara khusus. Oleh sebab itu perlu adanya sebuah penelitian pengembangan produk, untuk menghasilkan media pembelajaran bagi guru Bimbingan dan Konseling, sebagai upaya meningkatkan keterampilan siswa dalam mengatasi konflik interpersonal bagi siswa SMP.
\end{abstract}

Kata Kunci: Pengembangan Buku Teks, Bimbingan Sosial Berbasis Masalah, Kemampuan Siswa Mengatasi Masalah, Konflik Interpersonal.

\section{Pendahuluan}

Kehidupan masa remaja senantiasa menarik untuk dibicarakan karena kompleksnya permasalahan-permasalahan yang ada didalamnya. Masa remaja adalah masa yang menentukan, karena pada masa ini seorang anak mengalami banyak perubahan, baik fisik maupun psikis dengan rentang usia 12 atau 13 tahun sampai 19 tahun. Sepanjang masa remaja, hubungan sosial semakin tampak jelas dan sangat dominan. Persoalan-persoalan yang dialami remaja dalam menjalani hubungannya adalah kurang mam- pu beradaptasi dengan lingkungan sosialnya, kurang berprestasi dalam akademik, kurang percaya diri, kesulitan bergaul, dan berkonflik dengan teman sebayanya. Ketidakmampuan remaja dalam pengendalian emosi membuat mereka tidak peka terhadap perasaan sesama yang mengakibatkan para remaja tega menganiaya hingga membunuh sesamanya, dan hal ini kerap terjadi saat remaja tawuran. Adanya interaksi tersebut menyebabkan remaja juga mengalami beberapa persoalan dalam menjalani hubungannya dengan orang lain. Perilaku para pelajar dalam

1 Mahasiswa Jurusan Bimbingan dan Konseling FIP UNJ, tripina_tri@yahoo.com

2 Dosen Bimbingan dan Konseling FIP UNJ,

3 Dosen Bimbingan dan Konseling FIP UNJ, 
tawuran tidak menunjukkan bahwa ego sebagai sebuah kekuatan positif, melainkan ego hanya sebagai sebuah aktualisasi diri yang keliru. Bila siswa dapat mengelola konflik yang kerap terjadi pada dirinya, ia akan memiliki kemampuan pemecahan konflik interpersonal dan akan memberi efek yang baik bagi hubungan sosialnya.

Kemampuan menyelesaikan konflik interpersonal mempengaruhi siswa dalam mengelola emosinya, dapat bekerja sama, memiliki motivasi berprestasi, dan dapat berkompetisi secara sehat. Berdasarkan pernyataan guru BK yang mengatakan bahwa dirinya belum memiliki buku sebagai panduan dalam penanganan konflik, dan mengingat maraknya konflik yang terjadi, maka ada baiknya para pendidik membuat sebuah buku teks sebagai pedoman. Buku teks dibuat untuk guru BK sebagai panduan dalam memberikan bimbingan dalam mengajarkan langsung teknik penyelesaian konflik, khususnya konflik interpersonal sehingga siswa memiliki keterampilan dalam penanganan konflik. Buku teks merupakan buku yang memberikan petunjuk dalam sebuah pelajaran khususnya di sekolah. Pengembangan ilmu serta keahlian peserta didik dalam menyelesaikan konflik interpersonal dalam buku teks bersifat fleksibel, yakni dapat membelajarkan peserta didik sesuai dengan cara dan kecepatan belajar yang berbeda.

Rumusan masalah "Bagaimana mengembangkan buku teks bagi guru BK dalam media pembelajaran"? Penelitian pengembangan bidang bimbingan sosial ini bertujuan untuk menghasilkan suatu produk pembelajaran berbentuk buku teks yang dapat digunakan sebagai penunjang bagi guru BK ketika memberikan bimbingan kepada siswa dalam menangani konflik interpersonal.

\section{Kajian Teori \\ Bimbingan Sosial Berbasis Masalah Konflik In- terpersoanal}

Menurut pendapat Nurihsan et al.,bimbingan sosial berbasis masalah adalah suatu bimbingan atau bantuan untuk membantu para individu untuk memecahkan masalah-masalah sosial seperti hubungan dengan sesama teman, penyesuaian diri dengan lingkungan pendidikan dan masyarakat tempat tinggal mereka, dan penyelesaian masalah konflik. Jadi bimbingan sosial berbasis masalah konflik interpersonal adalah suatu pendekatan pembelajaran yang dimulai dengan menyelesaikan suatu masalah seseorang dengan orang lainnya karena memiliki perbedaan keinginan dan tujuan. Terdapat empat faktor yang mempengaruhi konflik interpersonal, yaitu (1) Sikap (Attitudes), (2) Persepsi (Perceptions), (3) Perbedaan Kebudayaan, dan (4) Perbedaan Kepentingan antara Individu atau Kelompok.

Strategi dasar yang digunakan dalam mengatasi konlik adalah Pemecahan Masalah (Problem Solving), meliputi usaha mengidentifikasi masalah, memisahkan kedua belah pihak dan mengembangkan serta mengarah kepada sebuah solusi yang memuaskan.

Menurut R.Ibrahim dan Nana Syaodih S Sintaks pembelajaran berbasis masalah adalah sebagaimana dapat dibaca pada tabel 2.1.:

Tabel 2.1

Sintaks Pembelajaran Berbasis Masalah

\begin{tabular}{|l|l|}
\hline \multicolumn{1}{|c|}{ Tahap } & \multicolumn{1}{c|}{ Langkah } \\
\hline $\begin{array}{l}\text { Tahap-1 } \\
\text { Orientasi siswa pada masalah }\end{array}$ & $\begin{array}{l}\text { Guru menjelaskan tujuan pembelajaran, } \\
\text { menjelaskan logistik yang dibutuhkan, mengajukan } \\
\text { fenomena atau demonstrasi atau cerita untuk } \\
\text { memunculkan masalah, memotivasi siswa untuk } \\
\text { terlibat dalam pemecahan masalah yang dipilih. }\end{array}$ \\
\hline $\begin{array}{l}\text { Tahap-2 } \\
\text { Mengorganisasi siswa untuk belajar }\end{array}$ & $\begin{array}{l}\text { Guru membantu siswa untuk mendefinisikan dan } \\
\text { mengorganisasi tugas belajar yang berhubungan } \\
\text { dengan masalah tersebut. }\end{array}$ \\
\hline $\begin{array}{l}\text { Tahap-3 } \\
\text { Membimbing penyelidikan individual } \\
\text { maupun kelompok }\end{array}$ & $\begin{array}{l}\text { Guru mendorong siswa untuk mengumpulkan } \\
\text { informasi yang sesuai, melaksanakan eksperimen } \\
\text { untuk mendapatkan penjelasan dan pemecahan } \\
\text { masalah. }\end{array}$ \\
\hline $\begin{array}{l}\text { Tahap-4 } \\
\text { Mengembangkan dan menyajikan } \\
\text { hasil karya }\end{array}$ & $\begin{array}{l}\text { Guru membantu siswa dalam merencanakan dan } \\
\text { menyiapkan karya yang sesuai seperti laporan, } \\
\text { video, dan model serta membantu mereka untuk } \\
\text { berbagi tugas dengan temannya. }\end{array}$ \\
\hline $\begin{array}{l}\text { Tahap-5 } \\
\text { Menganalisis dan mengevaluasi } \\
\text { proses pemecahan masalah }\end{array}$ & $\begin{array}{l}\text { Guru membantu siswa untuk melakukan refleksi } \\
\text { atau evaluasi terhadap penyelidikan mereka dan } \\
\text { proses-proses yang mereka gunakan. }\end{array}$ \\
\hline
\end{tabular}

\section{Metode Penelitian}

Penelitian dilaksanakan di beberapa Sekolah Menengah Pertama Negeri dan Swasta di daerah Jakarta. Sekolah tersebut antara lain: SMP Negeri 14 Jakarta Timur, SMP Labschool Rawa Mangun Jakarta Timur, SMP Diponegoro Sunan Giri Jakarta Timur, SMP Santa Maria Fatima Jakarta Timur, SMP YPI Pulo Gadung Jakarta Timur dan SMP Darussa'Adah Jakarta Utara. Metode yang digunakan dalam penelitian ini adalah metode Penelitian dan Pengembangan (Research and Development)/ R\&D yang dikembangkan oleh Borg dan Gall tahun 1983. Teknik pengumpulan data adalah mendokumentasi dan menganalisa buku ajar atau modul yang 
digunakan oleh guru BK dan siswa serta menggunakan teknik wawancara agar dapat mengkontruksi pemikiran, kejadian, kegiatan, motivasi, persepsi, kepedulian, pengalaman, serta opini mendalam tentang masalah.

Langkah-langkah penelitian yang digunakan adalah (1) pengumpulan informasi melalui Analisis Kebutuhan (needs assessment),(2) perencanaan yang mencakup merumuskan kemampuan, untuk menentukan urutan bahan, dan uji coba, (3) Pengembangan format produk awal yang mencakup penyiapan bahan-bahan pembelajaran, handbook dan alat-alat evaluasi, (4) Uji ahli atau Validasi, dilakukan dengan responden para ahli perancangan produk, (5) Revisi produk dilakukan berdasarkan hasil validasi.

\section{Hasil dan Pembahasan}

Pengembangan produk Buku Teks divalidasi oleh tiga ahli: (1) ahli media, (2) ahli materi, dan (3) guru, sebagai pengguna produk.

Hasil uji coba validator ahli media: Aspek Materi memiliki 10 indikator yang terpenuhi dengan baik dan 2 indikator sudah terpenuhi. Ada saran untuk aspek materi yaitu: Konsep perlu diurut secara praktis sesuai dengan tingkatan kelas. Aspek Kebahasaan memiliki 1 indikator yang terpenuhi sangat baik dan 7 indikator yang terpenuhi dengan baik. Keempat indikator dalam Aspek Penyajian sudah terpenuhi dengan baik. Dalam Aspek Efek Media Terhadap Strategi Pembelajaran, 5 indikator terpenuhi dengan baik. Pada aspek Tampilan Menyeluruh 5 indikator terpenuhi dengan sangat baik, 1 indikator terpenuhi dengan baik dan 1 indikator sudah terpenuhi.

Hasil uji coba validator ahli materi: Aspek Materi memiliki 1 indikator terpenuhi dengan sangat baik, 9 indikator terpenuhi dengan baik, dan 3 indikator sudah terpenuhi. Aspek Kebahasaan memiliki 1 indikator yang terpenuhi sangat baik dan 7 indikator yang terpenuhi dengan baik. Dalam Aspek Penyajian 5 indikator sudah terpenuhi dengan baik. Dalam Aspek Efek Media Terhadap Strategi Pembelajaran 4 indikator terpenuhi dengan baik, dan 1 indikator sudah terpenuhi. Pada aspek Tampilan Menyeluruh 4 indikator terpenuhi dengan baik, dan 1 indikator sudah terpenuhi. Kesimpulan umum dari ahli materi: berdasarkan kelayakan materi, kebahasaan, penyajian, efek terhadap strategi pembela- jaran dan tampilan menyeluruh, maka buku acuan bimbingan dan konseling ini dinyatakan "baik, terutama dalam pembahasannya".

Hasil uji coba Guru: Aspek Materi memiliki 8 indikator terpenuhi dengan sangat baik, 5 indikator terpenuhi dengan baik, guru BK mengatakan materi top/bagus dan ada satu saran mengenai materi yaitu: materi dapat disesuaikan dengan lingkungan sekolah. Aspek Kebahasaan memiliki 5 indikator yang terpenuhi sangat baik dan 3 indikator yang terpenuhi dengan baik, dalam aspek bahasa yang digunakan bagus karena novel style sesuai dengan gaya bahasa siswa SMP. Dalam Aspek Penyajian 2 indikator sudah terpenuhi dengan baik dan 2 indikator sudah terpenuhi. Dalam Aspek Efek Media Terhadap Strategi Pembelajaran 4 indikator terpenuhi sangat baik, dan 1 indikator terpenuhi dengan baik. Pada aspek Tampilan Menyeluruh 1 indikator terpenuhi dengan sangat baik, 1 indikator terpenuhi dengan baik, dan 1 indikator sudah terpenuhi. Kesimpulan umum dari guru: berdasarkan penilaian kelayakan materi, kebahasaan, penyajian, efek terhadap strategi pembelajaran dan tampilan menyeluruh, maka modul bimbingan konseling ini dinyatakan: "Sangat Baik".

Penelitian pengembangan buku teks memiliki beberapa kelebihan dan keterbatasan: Kelebihan dari produk pengembangan buku teks guru BK SMP adalah:

a) Memudahkan guru dalam mencari referensi mengenai materi penanganan dan pencegahan konflik khususnya konflik interpersonal.

b) Guru memiliki acuan langkah-langkah pembelajaran yang sudah jelas sehingga sangat membantu dalam proses bimbingan.

c) Materi penyelesaian konflik dalam buku acuan disampaikan secara bertahap sehingga dapat mempermudah pengguna buku dalam menyampaikan materi penyelesaian konflik kepada siswa.

Keterbatasan peneliti dalam pengembangan produk:

a. Membutuhkan banyak sekolah untuk pengambilan data.

b. Membutuhkan banyak buku BK untuk dianalisa.

c. Membutuhkan banyak responden (guru dan siswa) untuk diwawancara. 
d. Ada penolakan dari beberapa sekolah saat pengambilan data ketika mengetahui penelitian yang akan dilakukan adalah mengenai konflik khususnya konflik interpersonal.

e. Mengalami kesulitan saat menuangkan ide dalam membuat cerita untuk isi topik dalam buku teks.

f. Waktu pembuatan yang dibutuhkan cukup lama.

g. Membutuhkan konsentrasi dan konsistensi yang tingi dalam pembuatannya.

h. Memerlukan waktu yang lama dalam pengadaan atau pengembangan buku.

i. Membutuhkan biaya yang cukup tinggi untuk produksi.

j. Membutuhkan kejelian dalam menyesuaikan topik dengan tahap perkembangan siswa.

\section{Kesimpulan dan Saran}

\section{Kesimpulan}

Penelitian pengembangan model, bertujuan menghasilkan sebuah bahan ajar cetak berbentuk Buku Teks Bimbingan Sosial Meningkatkan Kemampuan Siswa Mengatasi Konflik Interpersonal. Tujuannya adalah sebagai sumber belajar baru mengenai keterampilan dalam penanganan konflik khususunya konflik interpersonal siswa. Melalui materi yang terdapat dalam buku, guru diharapkan mampu membimbing siswa berkomunikasi dengan baik untuk menghindari konflik. Siswa juga diharapkan mampu mengendalikan emosi untuk mencegah konflik, memiliki alternatif untuk pemecahan masalah, mampu menjalin hubungan yang harmonis dengan teman sebaya dan memiliki keinginan menyelesaikan konflik. Melalui produk buku teks ini, guru dapat meningkatkan kemampuannya dalam memberikan bimbingan sosial berbasis masalah untuk meningkatkan kemampuan siswa mengatasi konflik interpersonal.

\section{Saran}

Saran yang dapat diberikan berdasarkan hasil penelitian ini bagi pihak-pihak terkdalamait yaitu:

\section{Bagi Guru Bimbingan dan Konseling}

Sekolah sebagai lembaga pendidikan kedua setelah keluarga dan guru bertindak sebagai orangtua bagi para siswanya, dalam mengasuh, memimpin anak melalui kegiatan proses pembelajaran. Secara khusus Guru Bimbingan dan Konseling me- miliki sebuah buku teks sebagai panduan dalam menyelesaikan konflik interpersonal yang terjadi pada siswa di sekolah.

\section{Bagi Peneliti Selanjutnya}

Dapat melakukan penelitian mengenai pengembangan buku teks tentang kemampuan menyelesaikan konflik lainnya yaitu konflik intrapersonal dan konflik interorganisasi.

\section{Bagi Civitas Akademika Bimbinigan dan Konseling}

Dapat mempersiapkan calon-calon guru BK yang mampu membuat sebuah buku teks, sehingga memiliki pengetahuan dan keterampilan yang dapat diaplikasikan ketika menjadi guru disekolah. Hal tersebut dapat dilakukan de-ngan cara meninjau kurikulum, strategi perkuliahan S1-BK terkait mata kuliah mengenai pengembangan media pembelajaran dalm BK.

\section{Daftar Pustaka}

ndi Prastowo. 2011. Panduan Kreatif Membuat Bahan Ajar Inovatif. Jogjakarta: Diva Press.

Azhar Arsyad. 2006. Media Pembelajaran. Jakarta: PT. Grafindo Persada.

Barbara B Seels, Rita c Richey. 2008. Teknologi Pembelajaran: Definisi dan Kawasannya. Jakarta: Grafindo Persada.

Gerungan,W.A. 2009. Psikologi Sosial. Bandung: Refika Aditama.

M Atwi, Suparman. 2010. Desain Instruksional. Jakarta UT.

Pudji Muljono. 2001. Skripsi: Pedoman Penyusunan Modul Dalam Rangka Proses Belajar Mengajar Program Profesional. Bogor.

R. Ibrahim, Nana Syaodih S. 1995. Perencanaan Pengajaran. Jakarta: Rineka Cipta.

Rayandra Asyhar. 2011. Kreatif Mengembangkan Media. Jakarata: Gaung Persada Press.

Ronald H. Anderson. 1994. Pemilihan dan Pengembangan Media untuk Pembelajaran. Jakarta: Raja Grafindo Persada. 